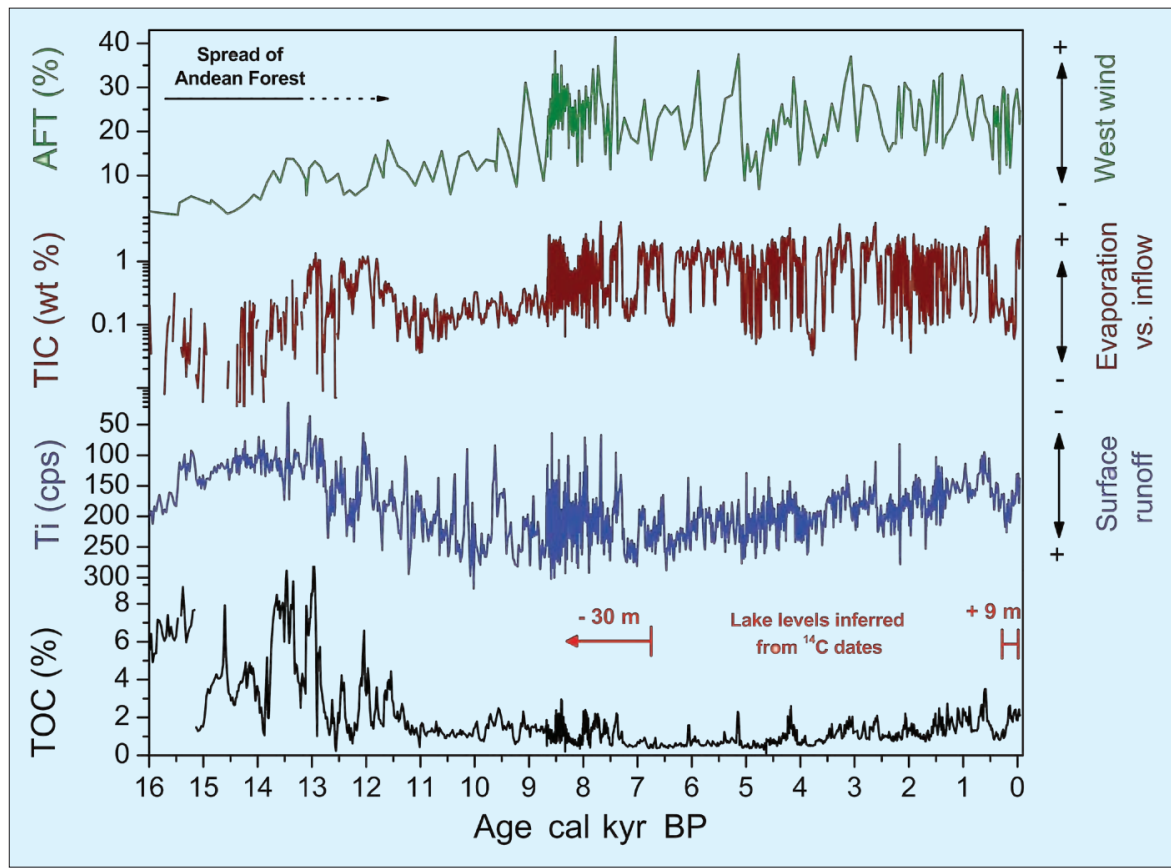

Figure 2: Climate proxies of the Laguna Potrok Aike sediment archive: Pollen of Andean Forest Taxa (AFT) as a measure of west wind variability, total inorganic carbon (TIC) as a proxy of the balance between evaporating and inflowing waters, and titanium content (Ti; given as counts per second-cps) representing minerogenic sedimentary input mainly by surface runoff. Note that Ti and AFT are influenced by other effects in the late glacial. Radiocarbondated lake levels relative to today are given by red bars. Total organic carbon (TOC) is plotted to demonstrate that there might be a dilution of Ti by organic matter during the late glacial.

\title{
References:
}

Haberzettl, T., Fey, M., Lücke, A., Maidana, N.I., Mayr, C., Ohlendorf, C, Schäbitz, F., Schleser, G.H., Wille, M. and Zolitschka, B., 2005: Climatically induced lake level changes during the last two millennia as reflected in sediments of Laguna Potrok Aike, southern Patagonia (Santa Cruz, Argentina), Journal of Paleolimnology, 33: 283-302.

Haberzettl, T., Corbella, H. Fey, M. Janssen, S. Lücke, A. Mayr, A Ohlendorf, C., Schäbitz, F., Schleser, G.H., Wille, M., Wulf, S. and Zolitschka, B., 2007: Lateglacial and Holocene wet-dry cycles in southern Patagonia: chronology, sedimentology and geochemistry of a lacustrine record from Laguna Potrok Aike, Argentina, The Holocene, 17(3): 297-311.

Haberzettl, T., Kück, B., Wulf, S., Anselmetti, F., Ariztegui, D., Corbella, H., Fey, M., Janssen, S., Lücke, A., Mayr, C., Ohlendorf, C., Schäbitz, F., Schleser, G.H., Wille, M. and Zolitschka, B., in press: Hydrological variability in southeastern Patagonia and explosive volcanic activity in the southern Andean Cordillera during Oxygen Isotope Stage 3 and the Holocene inferred from lake sediments of Laguna Potrok Aike, Argentina, Palaeogeography, Palaeoclimatology, Palaeoecology.

Mayr, C., Wille, M., Haberzettl, T., Fey, M., Janssen, S., Lücke, A., Ohlendorf, C., Oliva, G., Schäbitz, F., Schleser, G.H. and Zolitschka, B., 2007: Holocene variability of the Southern Hemisphere westerlies in Argentinean Patagonia $\left(52^{\circ} \mathrm{S}\right)$, Quaternary Science Reviews, 26: 579-584.

Wille, M., Maidana, N.I., Schäbitz, F., Fey, M., Haberzettl, T., Janssen, S Lücke, A., Mayr, C., Ohlendorf, C., Schleser, G.H. and Zolitschka, B., 2007: Vegetation and climate dynamics in southern South America: The microfossil record of Laguna Potrok Aike, Santa Cruz, Argentina, Review of Palaeobotany and Palynology, 146 234-246

\section{Tree-ring evidence for tropical-extratropical influences on climate variability along the Andes in South America} Ricardo Villalba

Departamento de Dendrocronología e Historia Ambiental, IANIGLA, Mendoza, Argentina; ricardo@lab.cricyt.edu.ar

Instrumental records show that the climate system is characterized by low- and high-latitude modes of variability, which fluctuate at many different temporal scales. The best known is the El NiñoSouthern Oscillation (ENSO) phenomenon in the tropical Pacific, which dominates global climate variations on interannual timescales mostly ranging from 3 to 6 years (Diaz and Markgraf, 2000). The Antarctic Oscillation (AAO) is the dominant mode of climate variability at mid- to high latitudes in the southern hemisphere (Thompson and Wallace, 2000). The positive state of this annular mode is associated with intensified subtropical highs and strong polar lows, which drive a strong extratropical circulation. Interannual-todecadal variability of climate associated with these atmospheric circulation modes exhibits large spatial and temporal variance that remains poorly documented. Continental- and hemispheric-scale networks of instrumental and proxy climate data are needed to document and help understand these changes in the oceanatmosphere system.

Tree rings represent the most broadly distributed, annually-resolved source of proxy climate data throughout the Andes Cordillera and, thereby, supply the base-

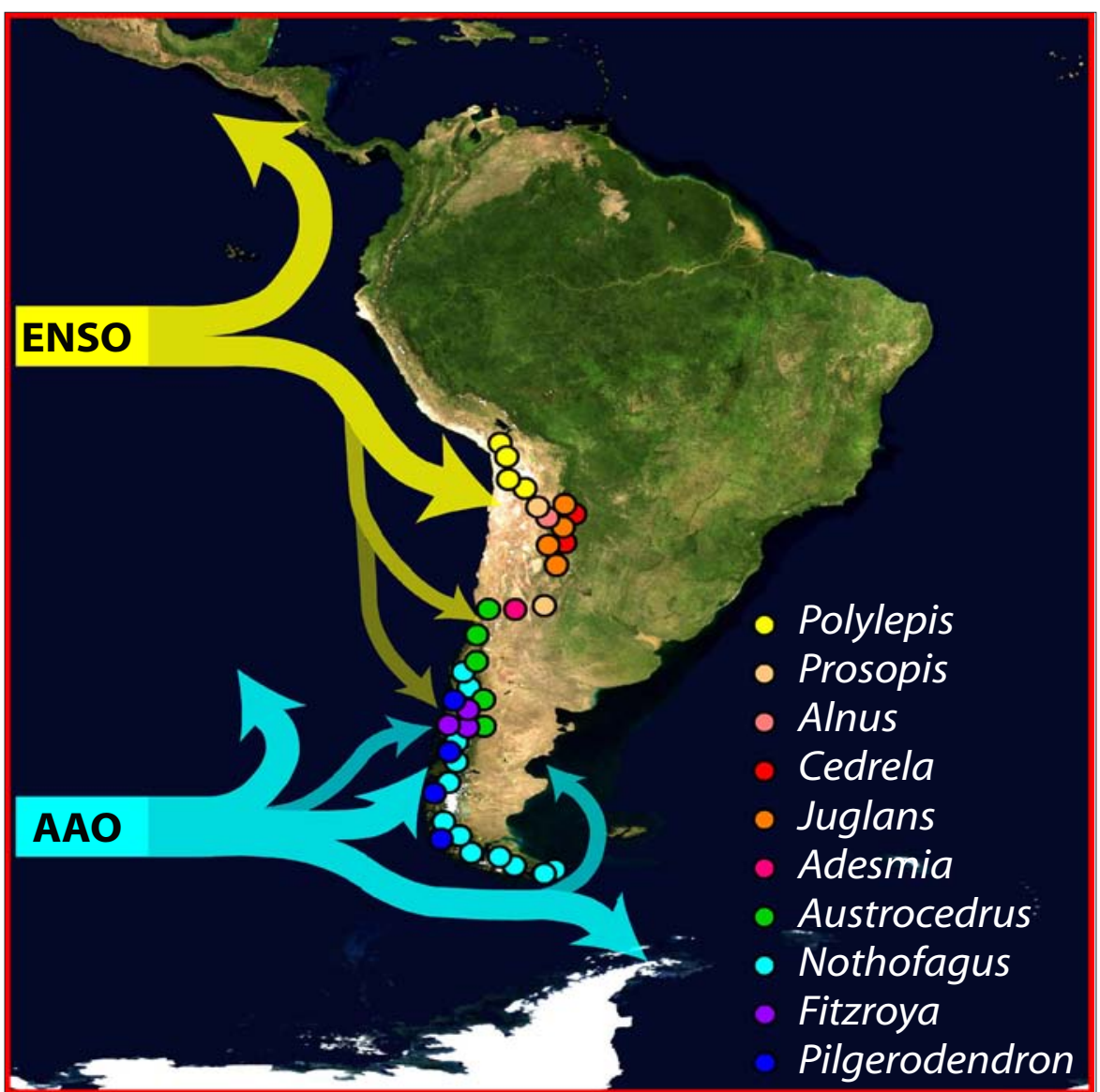

Figure 1: Tree-ring chronologies along the Andes Cordillera in South America. Major tree taxa used for developing the chronologies and their geographical distributions are shown. The geographical domain of the dominant tropical and extratropical forcings of regional climate variability across the Andes, as represented by the El Niño-Southern Oscillation (ENSO) and the Antarctic Oscillation (AAO), respectively, are also indicated. 
line data necessary to evaluate natural climate variability on different temporal and spatial scales (Fig. 1). A Collaborative Research Network supported by the InterAmerican Institute for Global Change Research (IAI) focused on the development of treeline chronologies from Alaska to Tierra del Fuego (Luckman and Boninsegna, 2001). Using a combination of instrumental and tree ring records, the southern component of this study shows how tropical versus extratropical forcings of climate variability influence regional patterns of temperature and precipitation variations from tropical Bolivia $\left(16^{\circ} \mathrm{S}\right)$ to sub-Antarctic, southern South America ( $55^{\circ} \mathrm{S}$ ).

\section{Tropical-extratropical forcings of regional temperature variations}

The continental effects of ENSO in terms of surface air temperature and precipitation vary along the Andes Cordillera. Positive anomalies in summer temperature across the Bolivian Altiplano are associated with increased westerly dry flow on the Altiplano during El Niño events (warm-ENSO phase). As a consequence, the eastern wet influences are reduced over the entire region leading to generally warm-dry summers (Fig. 2c). Conversely, during negative anomalies in the tropical Pacific sea surface temperatures (SSTs) (La Niña events or cold-ENSO phase), this pattern reverses (Vuille et al., 2000; Garreaud et al., 2003).

The radial growth of Polylepis tarapacana, a small tree growing between 4000 and $5200 \mathrm{~m}$ elevation on the Altiplano, is influenced by changes in summer temperature and precipitation (Argollo et al., 2004). P. tarapacana growth is significantly correlated ( $r=-0.42, n=138$; Fig. 2a) with variations in the Southern Oscillation Index (SOI), from August (previous to the growing season) to February (during the current year of ring formation), encompassing the peak of ENSO (Nov-Feb) when warm and cold events mature in the equatorial Pacific (Christie et al., in press).

At mid-latitudes $\left(39-43^{\circ} \mathrm{S}\right)$ in the $\mathrm{Pa}$ tagonian Andes, temperatures during summer (Dec-Mar) - as reconstructed for the past millennium using chronologies from Fitzroya cupressoides-are also related to variations in the SOI during the same season ( $r=-0.36, n=127$; Fig. $2 b$ ). There is a significant tendency for the occurrence of relatively warm and dry (cool and wet) conditions along the northwestern part of Patagonia, in Chile and adjacent Argentina during summers coincident with El Niño (La Niña) episodes (Fig. 2c). A larger frequency of anticyclonic circulation anomalies near the southern tip of South America during El Niño episodes contributes to the

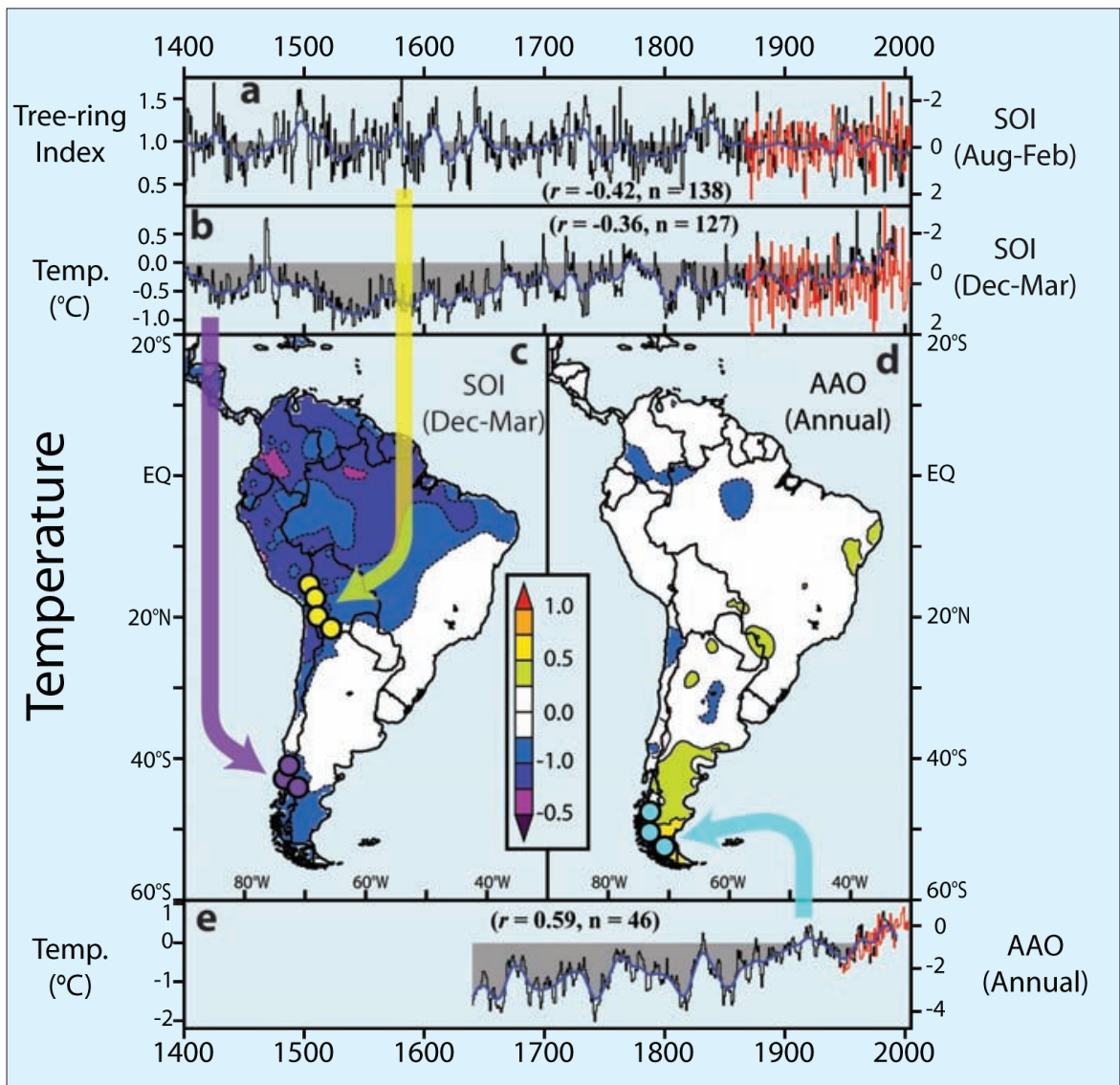

Figure 2: Temporal and spatial patterns of regional temperature variability along the Andes in South America related to tropical Pacific (Southern Ocillation Index; SOl) and extra-tropical (Antarctic Ocillation; AAO) atmospheric circulation features. SOl-related temperature variability recorded in tree-ring variations from (a) Polylepis tarapacana in the Bolivian Altiplano and (b) Fitzroya cupresoides in northwestern Patagonia. Spatial correlation patterns between summer (Dec-Mar) and annual (Aug-Sep) surface temperatures with (c) SOI and (d) AAO, respectively. Gridded temperature field from University of Delaware (1950-1999). Spatial correlations over \pm 0.25 are shown (roughly the threshold of the 95\% confidence level). (e) AAO-related temperature variability recorded in tree-ring variations from Nothofagus pumilio in southern Patagonia.

strengthening of the southern border of the subtropical Pacific anticyclone, which is located at its southern-most position during summer (Montecinos and Aceituno, 2003).

The positive polarity of the AAO is associated with cold anomalies over most of Antarctica, with the exception of the Antarctic Peninsula and southern South America, where the enhanced Westerlies related to the high AAO polarity increase the advection of relatively warm oceanic air over the land (Thompson and Solomon, 2002; Fig. 2d,e). Annual temperature variations in southern Patagonia, reconstructed from a network of upper-treeline Nothofagus pumilio chronologies (Villalba et al., 2003), are significantly correlated with annual variations in the AAO index. Warmer conditions during the 20th century, particularly in the past three decades, are consistent with more positive AAO values in recent times.

A gradual transition from tropical to high-latitude influences in temperature variations from northern $\left(40^{\circ} \mathrm{S}\right)$ to southern $\left(>47^{\circ} \mathrm{S}\right)$ Patagonia is consistent with temperature anomalies across the Pacific and western South America during ENSO. These anomalies are larger and more spa- tially consistent in northern than southern Patagonia, resulting in weaker influences of the tropical Pacific at higher latitudes in austral South America.

\section{Tropical-extratropical forcings of regional precipitation variations}

Precipitation variations in the Bolivian Altiplano and Central Chile are related to climate in the tropical Pacific (Fig. 3c,e). Interannual variability in summer precipitation, particularly on the western Altiplano, is related to ENSO (Fig. 3c; Vuille et al., 2000; Garreaud et al., 2003). Consistent with these findings, the precipitation-sensitive $P$. tarapacana records from the Altiplano are significantly correlated with the SOI during the 1866-2000 interval used for comparison ( $r=0.30$; Fig. 3a).

Relationships between SST in the equatorial Pacific and precipitation anomalies in central Chile (30-35 ${ }^{\circ}$ ) have been reported by several authors (Aceituno, 1988; Rutlland and Fuenzalida, 1991; Montecinos and Aceituno, 2003). The steeper gradient in pressure over the southeastern Pacific related to El Niño induces deflections of the low pressure systems, and the associated storms towards the subtropical belt of South America, increasing precipi- 


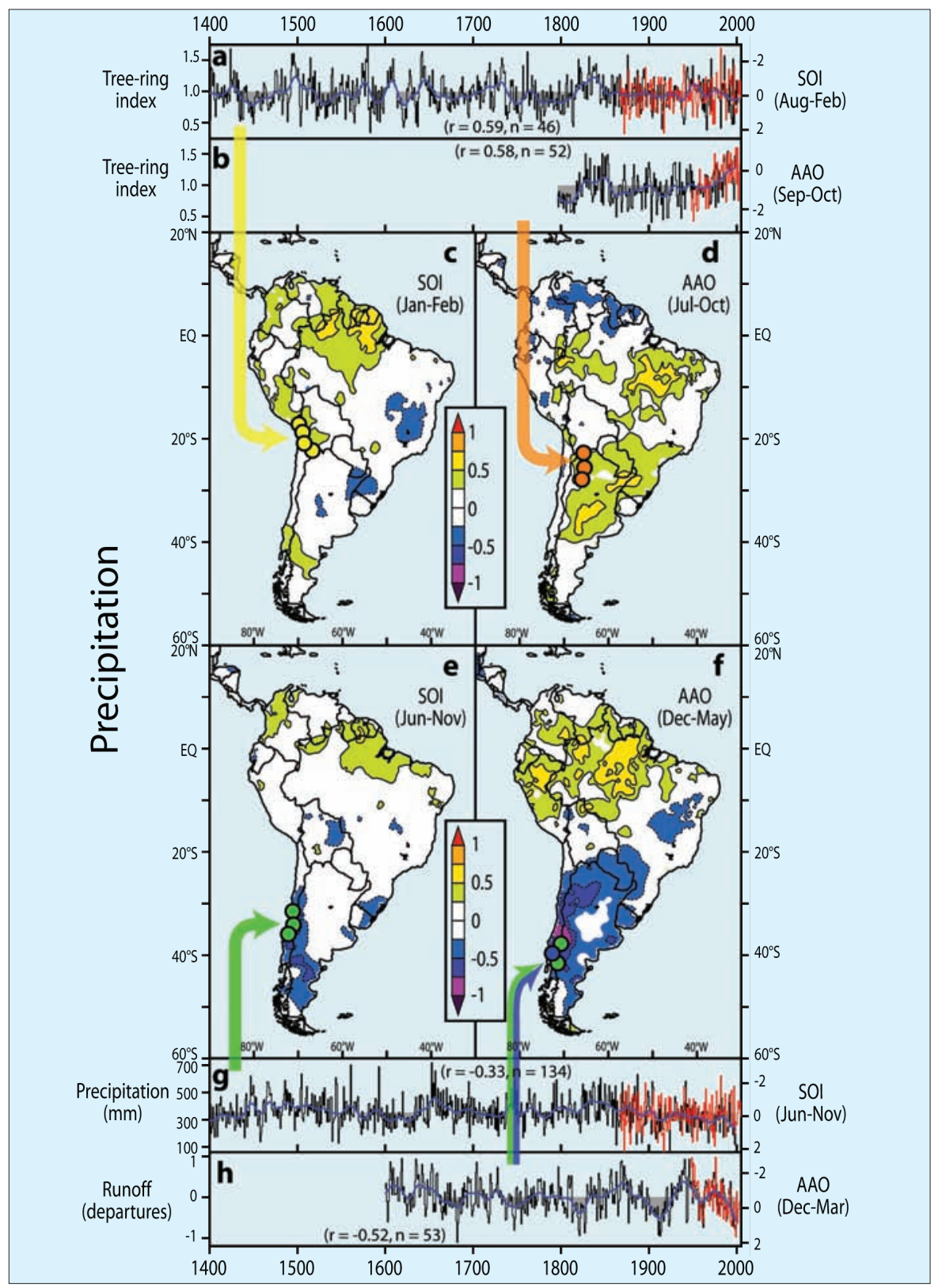

Figure 3: Temporal and spatial patterns of regional precipitation variability along the Andes in South America related to tropical Pacific (Southern Oscillation Index; SOI) and extra-tropical (Antarctic Oscillation; AAO) atmospheric circulation features. SOl-related precipitation variability recorded in tree-ring variations from Polylepis tarapacana in the Bolivian Altiplano (a) and Austrocedrus chilensis in central Chile (g). AAO-related precipitation variability recorded in tree-ring variations from Juglans australis in subtropical northwestern Argentina (b) and Austrocedrus chilensis-Pilgerodendron uviferum in northwestern Patagonia (h). Spatial correlation patterns between summer (Jan-Feb) and winter-spring (Jun-Nov) precipitation and SOI (c and e, respectively), and between winter (Jul-Oct) and summer-fall (Dec-May) precipitation and AAO (d and $\boldsymbol{f}$, respectively). Gridded precipitation field from University of Delaware (1950-1999). Spatial correlations over \pm 0.25 are shown (roughly the threshold of the $95 \%$ confidence level).

tation in Central Chile (Fig. 3e). Tree-ring based reconstructions of precipitation derived from Austrocedrus chilensis in central Chile (LeQuesne et al., 2006) show a consistent relationship with SOI (Jun-Nov) during the past 140 years $(r=-0.33$; Fig. $3 g$ ).

AAO-related precipitation anomalies have been documented along the subtropical eastern slopes of the Andes (24$30^{\circ} \mathrm{S}$ ) and in northern Patagonia $\left(38-42^{\circ} \mathrm{S}\right.$; Gillet et al., 2006). The positive AAO phase in winter-spring (Jul-Oct) is associated with the intensification of upper-level cyclonic activity, the enhancement of the moisture convergence and the increase in precipitation over the subtropics east sistent $A A O$ positive phase during the past three decades ( $r=058, n=52$; Fig. $3 b$ )

Negative precipitation anomalies during the positive polarity of the AAO in northern Patagonia are related to a reduction of the zonal flow at mid-latitudes that translate into less frontal and orographic precipitation in the Patagonian Andes (Fig. 3f; Garreaud, in press). Using a combination of Austrocedrus chilensis and Pilgerodendron uviferum tree ring records from the region, the summer-fall (DecMay) Puelo River streamflow has recently been reconstructed back to 1599 (Lara et al., 2007). Summer-fall runoff showed a significant negative correlation with the AAO ( $r=-0.52, n=53$; Fig. 3h), reflecting the influences of high-latitude atmospheric circulation on precipitation in northern Patagonia.

Climate fluctuations along the Andes exhibit considerable geographical dependence. Tropical and subtropical regions are mainly influenced by large-scale oscillations rooted in the tropical Pacific ocean, whereas climatic variations in the temperate and sub-Antarctic regions are closely related to mid-and high-latitude phenomena. However, climatic variations simultaneously modulated by tropicalextratropical interactions have also been reported for some regions in South America on the basis of instrumental (Silvestri and Vera, 2003) and proxy records (Villalba et al., in press). The network of climaticsensitive chronologies across the Andes offers the chance to develop longer data sets that will allow characterization of the full spectrum of regional temperature and precipitation variability, as well as their past interactions with tropical and extratropical circulation features. Understanding this variability is key to planning and mitigation of future climatic changes in South America.

\section{Acknowledgments}

I thank IAI and CONICET-Argentina for support of much of the work reported here. I am also grateful to many colleagues from IAI-CRN03 and IAI-CRN2047 who provided materials used in this contribution.

\section{References}

Garreaud, R., Vuille, M. and Clement, A. 2003: The climate of the Altiplano: Observed current conditions and mechanisms of past changes, Palaeogeography, Palaeoclimatolology, Palaeoecology, 194: 5-22.

Luckman, B.H. and Boninsegna, J.A., 2001: The Assessment of Present, Past and Future Climate Variability in the Americas from Treeline Environments, PAGES Newsletter, 9: 17-19.

Montecinos, A. and Aceituno, P., 2003: Seasonality of the ENSO-Related rainfall variability in Central Chile and associated circulation anomalies, Journal of Climate, 16: 281-296.

Thompson, D.W.J. and Wallace, J.M., 2000: Annular modes in the extratropical circulation. Part l: Month-to-month variability, Journal of Climate, 13: 1000-1016.

Villalba, R., Lara, A., Boninsegna, J.A., Masiokas, M., Delgado, S., Aravena, J.C., Roig, F.A., Schmelter, A., Wolodarsky, A. and Ripalta, A., 2003: Large-scale temperature changes across the southern Andes: 20th-century variations in the context of the past 400 years, Climatic Change, 59: 177-232.

For full references please consult:

www.pages-igbp.org/products/newsletter/ref2007_2.html 